Article available at http://Www.parasite-journal.org or nttp://dx.dol.org/10.1051/parasite/1997043283

\title{
AN HSP60-63 HOMOLOGUE IS CONSTITUTIVELY EXPRESSED IN INFECTIVE LARVAE OF TRICHINELLA SPIRALIS
}

\author{
ALLEGRETTI S., HAMBOURG C., HUYNH V.T. \& DUPOUY-CAMET J.*
}

\section{Summary :}

Western-blot analysis of Trichinella spiralis proteins were carried out with anti-HSP60-63 and anti-HSP9O antibodies. These experiments showed the presence of an homologue of HSP60-63 but no HSP9O homologue could be identified. Image analysis showed that HSP6O-63 represented approximatively $4 \%$ of the Trichinella proteic preparation. Immunofluorescence analysis on cryosections of infected muscles showed the presence of HSP6O63 throughout the body wall (except in the cuticle) and in digestive structures. On some sections, patches of fluorescence could be seen on the inner surface of the nurse cell membrane. In addition, the western-blot analysis of sera from two patients - out of 10 tested - showed antibodies against HSP6O-63

recombinant proteins.

KEY WORDS : Trichinella, HSP
Résumé : Présence à L'ÉTAT CONSTITUTIF d'Un homologue de PROTÉINES DE STRESS (HSP60-63) DANS LES LARVES INFESTANTES DE TRICHINELLA SPIRALIS

L'analyse par immuno-empreinte d'une préparation protéique de larves de Trichinella spiralis avec des anticorps dirigés contre des protéines de stress (HSP60-63 et HSP9O) a montré la présence d'un homologue de HSP60-63, représentant environ $4 \%$ de la préparation protéique. L'analyse en immunofluorescence de coupes de muscles infectés par le parasite a montré la présence de ces homologues de HSP60-63 dans la paroi du vers (à l'exception de la cuticule) et dans des structures digestives. Sur certaines coupes, des plages de fluorescence peuvent être observées à la face interne de la capsule du parasite. De plus, une étude par immunoempreinte du sérum de 10 patients infectés a montré, chez deux d'entre eux, la présence d'anticorps contre des HSP60-63 recombinantes.

MOTS CLÉS : Trichinella, HSP.

\section{INTRODUCTION}

T he role and importance of HSP in host-parasite relationship has been extensively analysed (Kaufmann, 1990; Polla, 1991). HSP are major antigens of parasites such as Brugia malayi, Mesocestoides corti (Young et al., 1990; Ernani et al., 1993). Ko et al. (1996) produced evidence of HSP synthesis in Trichinella larvae submitted to thermal stress and Boireau et al. (personal communication) have recently described a HSP 70 gene in T. britovi. If HSP synthesis during a physical or chemical stress is not surprising, nothing is known on the presence of constitutive HSP in crude Trichinella protein extracts. Previous western blotting analysis of Trichinella muscular larvae showed that most antigenic fractions were obtained between 45 and 90 kDa (Dupouy-Camet et al., 1988). Therefore, we searched to identify and quantify HSPs 60-63 and 90 in Trichinella larvae proteins.

\footnotetext{
* Laboratoire de Parasitologie, Hôpital Cochin, Université R. Descartes, 27, rue du Faubourg St. Jacques, 75014 Paris, France. Correspondence: Jean Dupouy-Camet.

Tel : 331423414 97. Fax : 33142341496.

Email : dupouyca (a) imaginet.fr
}

\section{MATERIALS AND METHODS}

\section{TRICHINELLA ISOLATE}

T he T. spiralis (TRLL, ISS 104) strain used in these experiments was obtained from one horsemeat related outbreak of 1985 and maintained in mice. Proteic preparations were made from larvae obtained after $\mathrm{HCl}$-pepsin digestion from muscles of OF1 Swiss male mice infected 14 weeks previously. The larvae were washed several times with distilled water, ground on ice with a minihomogenizer, sonicated, and centrifuged at 2,000 g and $4^{\circ} \mathrm{C}$ for $30 \mathrm{~min}$. The supernatant was lyophilized and its protein content determined.

\section{WESTERN BLOT ANALYSIS OF TRICHINELLA}

Proteic lyophilisates of Trichinella were solubilized in a sample buffer (2\% SDS, $10 \%$ glycerol, $0.5 \mathrm{M}$ Tris, $5 \%$ 2-mercaptoethanol) and analysed by electrophoresis through a $8 \%$ polyacrylamide gel and a $4 \%$ stacking gel (Serva, Saint-Germain-en-Laye, France), and then transferred to a nitrocellulose membrane (Trans- 
phor, Hoefer Scientific Instruments, San Francisco, California), as previously described (Dupouy-Camet et al., 1988). The membranes were blocked with Tris buffer saline (TBS: $0.05 \mathrm{M}$ Tris, $0.15 \mathrm{M} \mathrm{NaCl}$ ) containing $2 \%$ glycine and milk (Régilait, Lyon, France) and cut into strips.

Strips containing Trichinella proteins were incubated with a anti-HSP60-63 polyclonal antibody (StressGen, Victoria, Canada, SPA-805), prepared from the moth Heliothis virescens, and a monoclonal antibody antiHSP90 (StressGen, SPA-845), prepared from rat spleen cells. Controls included HSP60-63 (StressGen, SPP770) and HSP90 (StressGen, SPP-740) recombinant proteins. Positive and negative controls were these recombinant proteins incubated either with the corresponding monoclonal antibody or with sera from the animals in which the monoclonal antibodies were raised, respectively. Quantification of HSP content of a known amount of proteic crude extract $(25 \mu \mathrm{g})$ was made by comparing patterns obtained with a known amount of recombinant HSP with an Image analysis device (Viber-Lourmat Image analyzer).

\section{WESTERN BLOT ANALYSIS OF INFECTED PATIENTS}

HSP60-63 and 90 recombinant proteins were solubilized in a sample buffer, analysed by electrophoresis, and then transferred to a nitrocellulose membrane as described above. These blots were assayed with sera of 10 patients infected by T. spiralis during the horse meat related outbreak of December 1993 (DupouyCamet et al., 1994). These sera were taken out 34 months after infection.

\section{IMMUNO-LOCALISATION OF HSP HOMOLOGUES}

Frozen sections of Trichinella parasitized muscle, embedded in mouse liver, were prepared for immunofluorescence studies with the polyclonal anti-HSP6063. Anti-HSP60-63 and 90 antibody were diluted in Tris buffer saline (TBS: $0.05 \mathrm{M}$ Tris, $0.15 \mathrm{M} \mathrm{NaCl}$ ) containing $2 \%$ glycine and milk (Régilait, Lyon, France). Antibody binding was assayed by an anti-rabbit fluorescent antiglobulin (Sigma Chemical Company, St. Louis, Mi) diluted 1/100. Positive controls was a section of parasitized muscle incubated with a sera containing Trichinella antibodies. Negative control was a section of parasitized muscle incubated with a normal rabit serum (in which the HSP polyclonal antibody was raised) and then incubated with an antirabbit fluorescent antiglobulin (Sigma Chemical Company, St. Louis, Mi). After two washes with a phosphate buffer, the slides were examined under UV light.

\section{RESULTS}

he western blot analysis of Trichinella spiralis proteins with the anti-HSP60-63 polyclonal antibody, showed the presence of an homologue of HSP60-63; no HSP90 homologue could be identified with the anti-HSP90 monoclonal antibody (Fig. 1). Positive and negative controls with the recombinant proteins gave the expected results. Image analysis showed that HSP60-63 represented approximatively $4 \%$ of the Trichinella proteic preparation. In addition, the western blot analysis of sera from two patients - out of 10 tested - showed antibodies against HSP60-63 recombinant proteins.

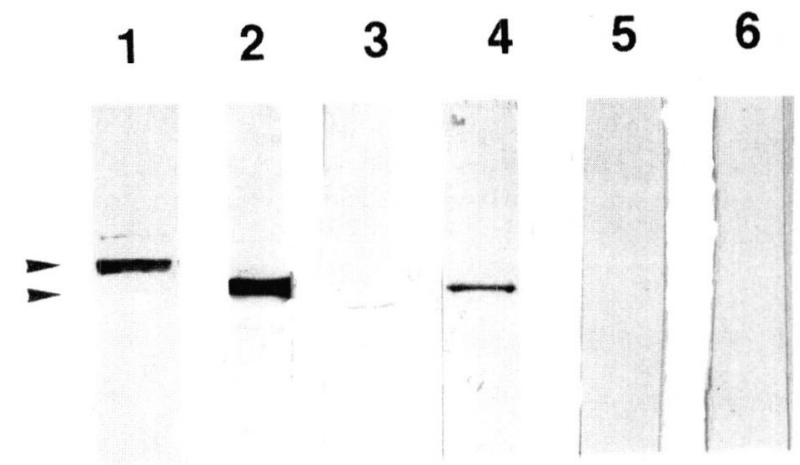

Fig. 1. - Analysis of Trichinella spiralis antigen by HSP antibodies. Lane 1: Mix of HSP60-63 and HSP90 assayed by HSP90 antibody. Lane 2: Mix of HSP60-63 and HSP90 assayed by HSP60-63 antibody. Lane 3: T. spiralis antigen assayed by HSP90 antibody. Lane 4: T. spiralis antigen assayed by HSP60-63 antibody. Lane 5: T. spiralis antigen assayed by uninfected rat serum. Lane 6: T. spiralis antigen assayed by uninfected rabbit serum. Arrows indicate 65 and $90 \mathrm{kD}$ molecular weights.

Immunofluorescence analysis on cryosections of infected muscles showed the presence of HSP60-63, under the cuticle throughout the body wall in structure which could be somatic muscles. Fluorescence was also seen in round structures, inside the worm, and which could correspond to digestive structures (oesophagus or intestine muscles?). On some sections, patches of fluorescence could be seen on the inner surface of the nurse cell membrane (Fig. 2). No HSP90 was detected by immunofluorescence.

\section{DISCUSSION}

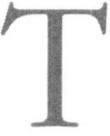
hese experiments show that HSP60-63 homologues are important components of the proteins of Trichinella larvae. Such homologues have also been found in other parasites: in Schistosoma mansoni, HSP 60 homologues represented 2 to $5 \%$ of the total cercarial proteins (Tielens et al., 1993). The 


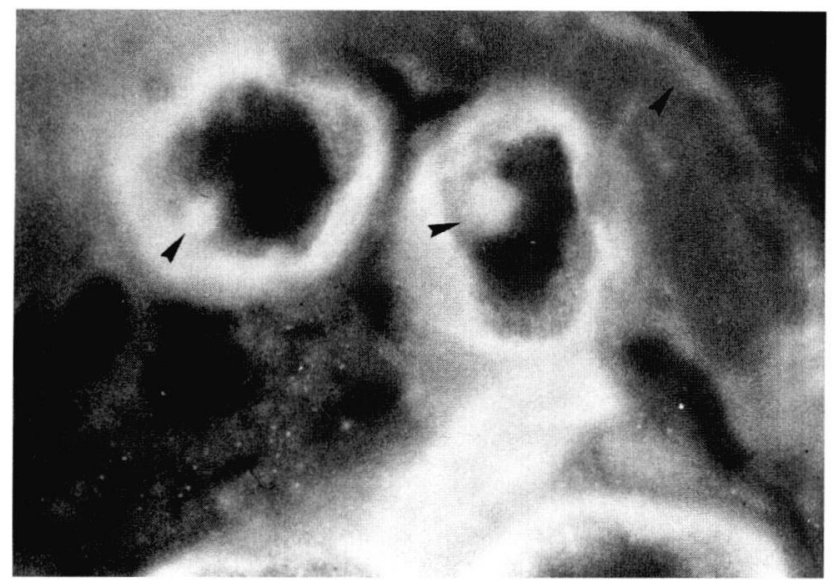

Fig. 2. - Immunofluorescence localisation of HSP60-63 in cryosections of T. spiralis larvae - HSP60-63 homologues were detected throughout out the body wall (except the cuticle), in digestive structures and possibly in the capsule (arrows).

possibility that $\mathrm{HCl}$-pepsin digestion of infected muscles could have triggered HSP synthesis, seems unprobable since larvae being immediately processed, the delay appears too short for a de novo synthesis. Moreover, the immunofluorescence assay confirms that HSP60-63 is constitutively expressed in intramuscular larvae. This assay also confirms that the HSPs detected in our experiments were truly of parasitic origin and not derived from bacteria which could have contaminated the crude extracts of Trichinella larvae. The presence of important amounts of HSP in Trichinella larvae could be a defense against the host digestive system. Moreover, as suggested for Schistosoma, constitutively expressed homologues of HSPs could induce a strong antibody response as these proteins are higly immunogenics (Tielens et al., 1993).

Two patients (out of 10) had antibodies against HSP6063 recombinant proteins. One of these two patients had antibodies against smooth muscle (1:100). Was this presence of antibodies coincidental or secondary to Trichinella infection? Could the high fraction of HSP6063 homologue in T. spiralis favour the occurrence of auto-antibodies, as suggested for mycobacterial infections (Tsoulfa et al., 1989; Haregewoin et al., 1991)? Immunofluorescence assays possibly evidenced HSP6063 homologues in the inner part of the capsule. Ko et al. (1996) demonstrated the presence of HSP65 in excretory/secretory products of Trichinella. The cestode parasite Mesocestoides corti is known to release at the larval stage several molecules including HSP70 and HSP60 (Ernani \& Teale, 1993). Our results suggest that HSP could be present in the parasitised muscle cell; but are these HSP homologues from parasitic origin or witnesses of a suffering parasitised cell? This point could be clarified by using monoclonal antibo- dies raised against Trichinella HSPs. Bornman et al. (1995) showed that heat shock proteins could be involved in muscular diseases pathogenesis by interfering with the metabolism of the muscular cell. Could HSP proteins of Trichinella origin interfere with the metabolism of parasitized muscular cells?

\section{ACKNOWLEDGEMENT}

This work was supported by ADERMEPT.

\section{REFERENCES}

Bornman L., Polla B., Lotz B.P. \& Gericke G. Expression of heat-shock/stress proteins in Duchenne muscular dystrophy. Muscle \& Nerve, 1995, 18, 23-31.

Dupouy-Camet J., Bougnoux M.E., Ancelle T., Fagard R. \& LAPIERRE J. Antigenic characteristic of two strains of Trichinella spiralis isolated during the horsemeat-related outbreaks of 1985 in France. Parasitology Research, 1988, 75, 79-80.

Dupouy-Camet J., Soulé C. \& Ancelle T. Recent news on trichinellosis: another outbreak due to horsemeat consumption in France in 1993. Parasite, 1994, 1, 99-103.

ERnani F. \& TEale J.M. Release of stress proteins from Mesocestoides corti is a brefeldin A-inhibitable process: evidence for active export of stress proteins. Infection E Immunity, 1993, 61, 2596-2601.

Haregewoin A., Singh B., Gupta R.S. \& Finberg R.W. A mycobacterial heat-shock protein-responsive $\mathrm{T}$ cell clone also responds to the homologous human heat-shock protein: A possible link between infection and autoimmunity. Journal of Infectious Diseases, 1991, 163, 156-160.

Kaufmann S.H.E. Heat shock proteins: a missing link in the host-parasite relationship? Medical Microbiology \& Immunology, 1990, 179, 61-66.

Ko R.C. \& FAN L. Heat shock response of Trichinella spiralis and T. pseudospiralis. Parasitology, 1996, 112, 89-95.

Polla B.S. Heat shock proteins in host-parasite interactions. Immunology Today, 1991, 7, A38-A41.

Tielens A.G.M., van den Heuvel J.M. \& van Eden W. Schistosoma mansoni: an HSP60 homologue is constitutively expressed in cercariae, adults and sporocysts. Experimental Parasitology, 1993, 77, 495-497.

Tsoulfa G., Rook G.A.W., Bahr G.M., Sattar M.A., Behbehani K., Young D.B., Mehlert A., Van-Embden J.D.A., Hay F.C., Isenberg D.A. \& Lydyard P.M. Elevated IgG antibody levels to the mycobacterial $65-\mathrm{kDa}$ heat shock protein are characteristic of patients with rheumatoid arthritis. Scandinavian Journal of Immunology, 1989, 30, 519-527.

Young D.B. \& Mehlert A. Stress proteins and infectious diseases In: Stress Proteins in biology and medicine. Morimoto R. (ed.), Cold Spring Harbor Laboratory Press, 1990, 131-165.

Reçu le 6 février 1997 Accepté le 9 mai 1997 